\title{
Effect of the Pasteurization Process and the Addition of Lactic Cultures in Costeño Cheese Quality
}

\author{
Serpa-Fajardo José* , Hernández-Ramos Elvis and Polo-Corrales Liliana
}

Department of Agro-Industrial Engineering. Innovation and Development of Food Processes (DESINPA). Universidad de Sucre, Sincelejo-Sucre, 70001. Colombia; jose.serpa@unisucre.edu.co, elvis.hernandez@unisucre.edu.co, liliana.polo@unisucre.edu.co

\begin{abstract}
Objective: This study evaluated the incidence of the process of pateurization and the addition of lactic cultures on the yield, as well as the physical-chemical, microbiological and sensorial quality of the costeño cheese. Methods/Analysis: Four treatments in a completely random design were evaluated: $\mathrm{T}_{1}$ : Sample control, cheese elaborated with fresh milk (raw), $\mathrm{T}_{2}$ : Cheese elaborated with pasteurized milk, $\mathrm{T}_{3}$ : Cheese elaborated with pasteurized milk and a mixture of three Lactobacillus (L. bulgaricus, L. casei, L. helveticus) and Streptococcus thermophilus, commercially known as MT12 $1.5 \% \mathrm{v} / \mathrm{v}$; and T. Cheese elaborated with pasteurized milk and a mixture of two Lactococcus (L. lactis and L. cremoris) with the commercial mixture $\mathrm{MT}_{12} 1.5 \%$ v/v. Sensory analysis was developed with 63 panelists through hedonic test (9-point scale). Findings: Results showed that pasteurization did not affect yield relative to control, but it increased significantly by adding lactic acid cultures. There was also increase in humidity. Protein percent decreased significantly by adding culture, while fat content, counting of both molds and yeasts decreased significantly in all treatments with respect to the sample control. Treatments $\mathrm{T}_{3}$ and $\mathrm{T}_{4}$ had the highest acceptance and although they did not present significant differences, $\mathrm{T}_{3}$ obtained higher evaluation. Improvement: The use of acid cultures is a technological alternative for Costeño cheese making because it allows getting a product of better acceptance and greater yield compared to traditional product (Costeño cheese) made with fresh milk (raw) without culture addition.
\end{abstract}

Keywords: Casei, Helvetica, Lactobacillus, Lactococcus, Streptococcus

\section{Introduction}

In the past five years (2012-2017), Colombia has sustained a yearly production average of 6.574 million liters of raw milk, with an annual average collection of 3.000 million liters $\stackrel{1}{-}$. Based on this production, Colombia ranks as the fourth largest raw milk producer in Latin America, below countries like: Brazil, Mexico and Argentina ${ }^{2}$. In terms of consumption, milk is one of the most important foods of Colombians' diet, who invest $2.5 \%$ of their total income in the purchase of dairy products ${ }^{3}$.

Costeño cheese is a typical gastronomic product made with milk usually fresh (raw), in the Colombian Caribbean region. Traditional technique of production does not include application of heat treatment to allow final product safety and innocuity, affecting shelf life. Appearance is usually rectangular with creamy color, open texture and dry consistency. Additionally, Costeño cheese chemical composition shows high fat and salt content $t^{4,5}$.

The Pasteurization process is used in the elaboration of several types of cheese to eliminate pathogenic microorganisms and reduce those causing defects in product properties ${ }^{6}$. In addition, some countries have restrictions on production or cheese importation made with unpasteurized milk ${ }^{7}$. Applied heat treatments must preserve milk coagulation and reduce undesirable microorganisms' species. However, the pasteurization process destroys the native microorganisms of the fresh milk (raw), so addition of lactic starter cultures is essential to guarantee acidification of fresh milk $\frac{8,9}{}$.

Lactic starter bacteria are very commonly used in cheese technology, prevailing over native milk flora. However, use must be controlled because it could cause losses of sensory properties of end-products, causing 
cheeses different from those made by traditional and/ or native technologies. Application of microorganisms adapted to production environment, local raw materials and traditional technology provide a product with typical characteristics that cannot be reproduced elsewhere ${ }^{10}$. Thus, objective of this study is to evaluate the incidence of the pasteurization process and the use of lactic cultures on the quality of the cheese in terms of its physical-chemical, microbiological and sensory properties.

\section{Materials and Methods}

\subsection{Materials}

To elaborate cheeses, fresh milk (raw) of Cebu cows located in the municipality of Betulia - Sucre, Colombia was raised. For the taking of the sample, a lactation period of the seven-month old cows was taken into account. The starter lactic cultures were commercial lyophilized (BIOLACT AEB Argentina S.A). Alquería brand pasteurized milk with $2.0 \%$ fat is used in the preparation of the culture substrate.

\subsection{Starter Culture Preparation}

The initial cultures were prepared with 1 liter of pasteurized milk and the addition of $1 \mathrm{~g}$ of lyophilized culture. The inoculation of two culture mixtures was carried out: the first, commercial mixture $\mathrm{MT}_{12}$ (Lactobacillus casei, L. bulgaricus, L. helveticus and Streptococcus thermophilus) at $42{ }^{\circ} \mathrm{C}$ and the other, Lactococcus lactis and Lactococcus cremoris with commercial mixture $\mathrm{MT}_{12}$ (1: 1$)$ at room temperature $\left(27^{\circ} \mathrm{C}\right)$. The two inocula were incubated for $2 \mathrm{~h}$.

\subsection{Fresh Milk Characterisation Physical- chemical}

Fresh milk was characterized by determining the physical-chemical properties of acidity, density, percentage of protein, fat, total solids, non-fat solids and lactose content. A milk analyzer LAC-S (BOECO, 100-240 V, $50-60 \mathrm{~Hz}$ ) calibrated following the methods established by the Association of Official Analytical Chemists (AOAC) was used ${ }^{11}$. Titratable acidity was calculated, for this, it was taken into account the method AOAC 947.05/90.

\subsection{Cheese Manufacturing Process and}

\section{Treatments}

To elaborate, cheeses were taken into account the methodology described by $\frac{12,13}{}$ (Figure 1). Treatments were applied as follows: Treatment $1\left(\mathrm{~T}_{1}\right)$ : Sample control, cheese elaborated with Fresh milk, Treatment $2\left(\mathrm{~T}_{2}\right)$ : Cheese elaborated with pasteurized milk, Treatment $\left(\mathrm{T}_{3}\right)$ : Cheese elaborated with pasteurized milk and a commercial mixture MT12; Treatment $4\left(\mathrm{~T}_{4}\right)$ : Cheese elaborated with pasteurized milk a mixture of L. lactis and L. cremoris and Commercial Mixture $\mathrm{MT}_{12}(1: 1)$.

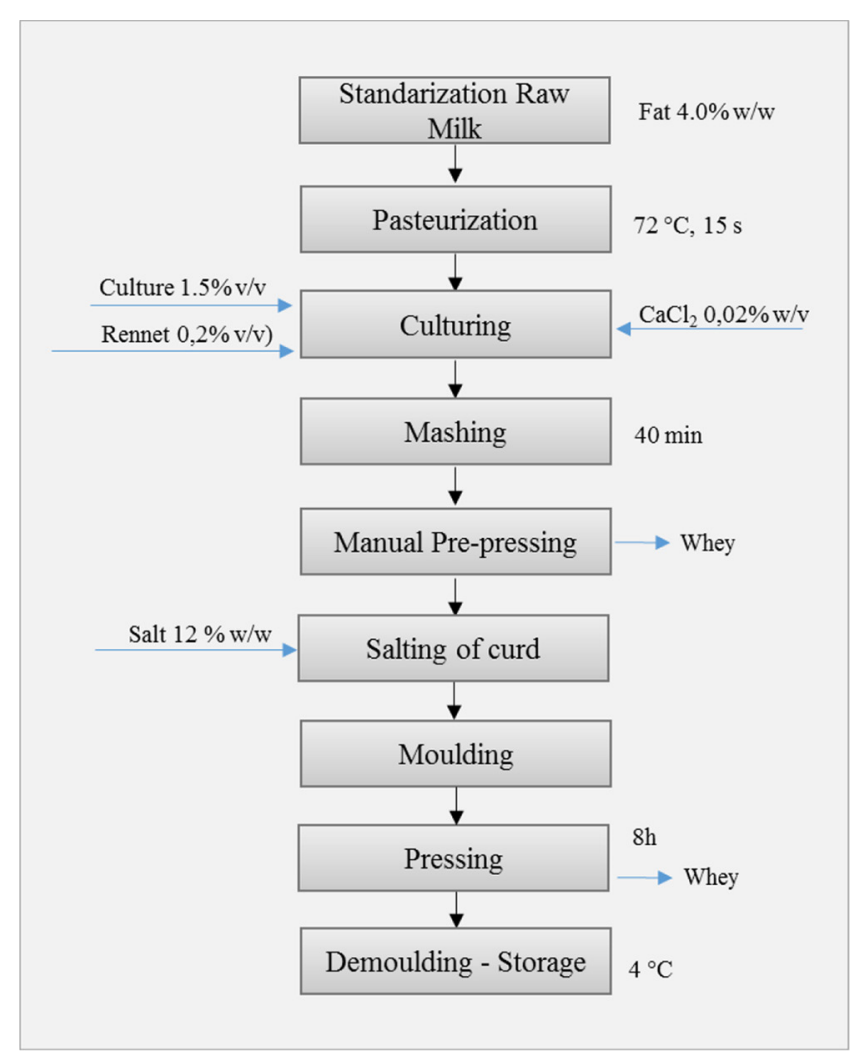

Figure 1. Cheese making process $\frac{13}{3}$.

\subsection{Physical-chemical Analysis of Cheese}

The analysis of the physical-chemical characteristics of the cheese was determinate according the methodology described by the AOAC. The acidity was carried out by titration, taking as reference the standard established by AOAC, 497.05, 2000.

The moisture content was calculated according to what is established in the norm of the AOAC 934.06, the protein and fat content as described the AOAC 920.152 
and AOAC 989.04 / 90 respectively. The $\mathrm{pH}$ of the treatments was determinate using a $\mathrm{pH}$-meter (Metrohm swiss made), following to the AOAC 981.12 / 90 method. With reference the cheese yield, it was calculated according to the weight in $\mathrm{Kg}$ of cheese obtained for each $\mathrm{Kg}$ of initial fresh milk.

\subsection{Microbiological Analysis of Cheese}

For the microbiological analysis, samples of the treatments were taken after five days of storage in refrigeration. Colony forming units were evaluated in coliforms, molds and yeasts following the procedures established in the Colombian Technical Standard (NTC) 4516 for the first and NTC 4132 for the last two. The counts of Sthapilococcus aureus and Salmonella were carried out according to the NTC 4779 and NTC 4574, respectively.

\subsection{Sensory Evaluation}

An acceptance test of the treatments was carried out using a hedonic scale of nine points. The scores of the scale were defined as follows: I like it extremely (9), I like it a lot (8), I like it moderately (7), I like it slightly (6), I do not like it or dislike it (5), I dislike it slightly (4), I dislike moderately (4), I dislike it a lot (2), I dislike it extremely (1). The sensory panel consisted of 63 untrained panelists, who performed the sensory evaluation taking into account the differences in treatments based on general acceptability.

\subsection{Statistical Analysis of the Data}

A randomized experimental design was carried out. The results obtained were analyzed statistically by Analysis Of Variance (ANOVA) using R v.2.9.1. The sensory evaluation was determined using a randomized block design. The significant differences that resulted from the ANOVA were analyzed using the Friedman test. Least squares means separation was performed using Tukey's test. All experiments were performed in triplicate. Significance was assessed at the $P \leq 0.05$ level.

\section{Results and Discussion}

\subsection{Physical-chemical and Microbiological Analysis of Fresh Milk (raw)}

The results obtained in the analysis of the physical-chemical parameters of fresh milk are shown in Table 1. All these results are in accordance with the ranges allowed by the Ministry of Social Protection of Colombia, who reports these parameters in its decree 616 (2006).

Table 1. Fresh milk composition

\begin{tabular}{|l|c|}
\hline Analysis & Average \\
\hline Acidity $(\%)^{1}$ & $0.18 \pm 0.01$ \\
\hline Density $\left(\mathrm{g} \mathrm{mL}^{-1}\right)$ & $1.02 \pm 0.00$ \\
\hline Fat $(\%)$ & $4.54 \pm 0.14$ \\
\hline Protein (\%) & $3.72 \pm 0.06$ \\
\hline Total Solids (\%) & $13.45 \pm 0.20$ \\
\hline Non-Fat Solids (\%) & $8.92 \pm 0.10$ \\
\hline Lactose (\%) & $5.04 \pm 0.11$ \\
\hline
\end{tabular}

${ }^{1}$ Described as a percentage of Lactic acid

Table 2 shows the results obtained during the microbiological analyzes of both fresh milk and pasteurized milk. The values are within the ranges allowed in Colombia, reported by Colombian Technical Standards 399 and 506 (NTC399 and NTC506) for fresh milk and pasteurized milk respectively.

Table 2. Microbial analysis of milk (fresh and pasteurized)

\begin{tabular}{|c|c|c|c|c|c|}
\hline \multicolumn{6}{|c|}{ Fresh Milk Microbial Analysis } \\
\hline \multicolumn{5}{|c|}{ Mesophilic aerobic (UFC)/mL } & $\begin{array}{c}\text { Listeria } \\
\text { spp. }\end{array}$ \\
\hline \multicolumn{5}{|c|}{650.000} & $\begin{array}{c}\text { Not } \\
\text { Found }\end{array}$ \\
\hline \multicolumn{6}{|c|}{ Pasteurized Milk Microbial Analysis } \\
\hline $\begin{array}{l}\mathrm{MA} \\
(\mathrm{UFC} \\
\left.\mathrm{mL}^{-1}\right)\end{array}$ & $\begin{array}{c}\mathrm{TC} \\
(\mathrm{Bac} / \\
\mathrm{mL})\end{array}$ & $\begin{array}{c}\mathrm{FC} \\
\mathrm{Bac} / \mathrm{mL}\end{array}$ & $\begin{array}{c}\text { YM } \\
(\mathrm{UFC}) / \\
\mathrm{mL}\end{array}$ & $\begin{array}{c}\text { S. aureus } \\
\text { (UFC)/ } \\
\text { mL }\end{array}$ & $\begin{array}{c}\text { Salmonella } \\
\text { (UFC)/ } \\
\text { mL }\end{array}$ \\
\hline 6000 & 4 & $<1$ & $\begin{array}{c}\text { Not } \\
\text { Found }\end{array}$ & $\begin{array}{l}\text { Not } \\
\text { Found }\end{array}$ & $\begin{array}{l}\text { Not } \\
\text { Found }\end{array}$ \\
\hline
\end{tabular}

MA: Mesophilic Aerobic, TC: Total Coliforms, YM: Yeast and Molds

\subsection{Physical-chemical Analysis of Cheese}

In Table 3 are shown the results of physical-chemical parameters of treatments. Acidity showed related results without statistically significant difference between control $\left(\mathrm{T}_{1}\right)$ and treatments $\mathrm{T}_{2}$ and $\mathrm{T}_{3}(0.41$ vs 0.35 and 0.41$)$. The highest acidity was found in $\mathrm{T}_{4}(1.03)$, in which a greater number of species of lactic bacteria were used. 
Table 3. Physical-chemical parameters of Costeño cheese*

\begin{tabular}{|l|c|c|c|c|c|}
\hline & Acidity (\%)** & $\mathrm{pH}$ & Moisture (\%) & Protein (\%) & Fat (\%) \\
\hline $\mathrm{T} 1^{* * *}$ & $0.40 \pm 0.03^{\mathrm{b}}$ & $6.27 \pm 0.02^{\mathrm{a}}$ & $46.76 \pm 0.27^{\mathrm{c}}$ & $14.51 \pm 0.39^{\mathrm{a}}$ & $15.25 \pm 0.25^{\mathrm{a}}$ \\
\hline $\mathrm{T} 2$ & $0.35 \pm 0.01^{\mathrm{b}}$ & $6.46 \pm 0.03^{\mathrm{a}}$ & $47.38 \pm 0.55^{\mathrm{bc}}$ & $14.31 \pm 0.37^{\mathrm{a}}$ & $13.40 \pm 0.39^{\mathrm{b}}$ \\
\hline $\mathrm{T} 3$ & $0.41 \pm 0.02^{\mathrm{b}}$ & $5.87 \pm 0.03^{\mathrm{a}}$ & $48.48 \pm 0.23^{\mathrm{b}}$ & $10.99 \pm 0.26^{\mathrm{b}}$ & $13.13 \pm 0.43^{\mathrm{b}}$ \\
\hline $\mathrm{T} 4$ & $1.03 \pm 0.03^{\mathrm{a}}$ & $5.02 \pm 0.01^{\mathrm{b}}$ & $50.70 \pm 0.14^{\mathrm{a}}$ & $12.24 \pm 0.26^{\mathrm{b}}$ & $12.62 \pm 0.38^{\mathrm{b}}$ \\
\hline
\end{tabular}

${ }^{\star}$ Mean with different letters in columns indicate statistically significant difference, Tukey $(\mathrm{p}<0.05)$.

${ }^{* *}$ Percentage described based on lactic acid

${ }^{* * *}$ Control Treatment

Analysis of variance showed a significant difference between this acidity and that reported for the other treatments. The basis of these results could be in the content of lactic acid produced by the commercial lactic cultures used, which increase the acidity. Indeed, there is a direct relationship between the acidity and the production of lactic acid in dairy products and specifically in cheeses $\frac{14,15}{}$. For $\mathrm{pH}$, values obtained agreed with those of acidity, with higher acidity and lower $\mathrm{pH}$ in the treatments.

Related results on $\mathrm{pH}$ behavior in cheeses inoculated with starter cultures of Lactococcus lactis for further ripening was reported by ${ }^{16}$. In this study, $\mathrm{pH}$ decreased from 6.6 in inoculated milk to 5.3 in the curd after drainage; due to conversion of lactose to lactic acid by ${ }^{17}$ reported a $\mathrm{pH}$ of 5.4 in stretched curd Mexican cheeses inoculated with lactic cultures during making process. Other studies show similar behavior for acidity and $\mathrm{pH}$ in the production of different types of cheese using lactic starter cultures $\frac{18,19}{}$.

Generally, pasteurization causes a slight denaturation of serum proteins ( $\alpha \mathrm{S} 1$ and $\beta$ caseins), changes in milk coagulation capacity, and produces cheeses with higher moisture content than those made with raw milk ${ }^{20}$. In this research, the pasteurization process did not have a significant effect on moisture content and protein percent of cheese processed with pasteurized milk $\left(\mathrm{T}_{2}\right)$ in relation to the control made with raw milk $\left(\mathrm{T}_{1}\right)$. However, addition of lactic acid cultures resulted in significant increases in moisture and significant decrease in proteins percent in $\mathrm{T}_{3}$ and $\mathrm{T}_{4}$ treatments compared to control. This result could be due both to the capacity of the starter cultures to retain water $\frac{21}{2}$, as well as to the biochemical processes of enzymes proteolysis produced by these microorganisms $\frac{12,20}{}$.

There were significant differences in the fat content of the treatments made with pasteurized milk, regard- less of the addition or not of lactic cultures $\left(\mathrm{T}_{2}, \mathrm{~T}_{3}\right.$ and $\mathrm{T}_{4}$ ) with respect to the control treatment $\left(\mathrm{T}_{1}\right)$ due to the break of fat globules $\frac{17,20,22,23}{}$. Furthermore, lactic cultures can break down fats into simpler compounds ${ }^{24}$, suggesting a decrease in values found in the fat content of $\mathrm{T}_{3}$ and $\mathrm{T}_{4}$ treatments.

\subsection{Percent Yield (w/w) in the Elaboration Process of Cheese}

Pasteurization did not significantly affect Costeño cheese performance. However, this parameter presented a statistically significant increase with the use of starter lactic cultures, from 19.04 for $\mathrm{T}_{1}$ (control) to 21.7 and 22.49 for treatments $\mathrm{T}_{3}$ and $\mathrm{T}_{4}$ respectively (Figure 2). This increase can be based in the higher serum retention caused by microorganisms or to the binding of serum proteins to casein $\frac{17,20,22,25}{}$. The higher yield values of $\mathrm{T}_{3}$ and $\mathrm{T}_{4}$ treatments coincide with the higher moisture values of these treatments.

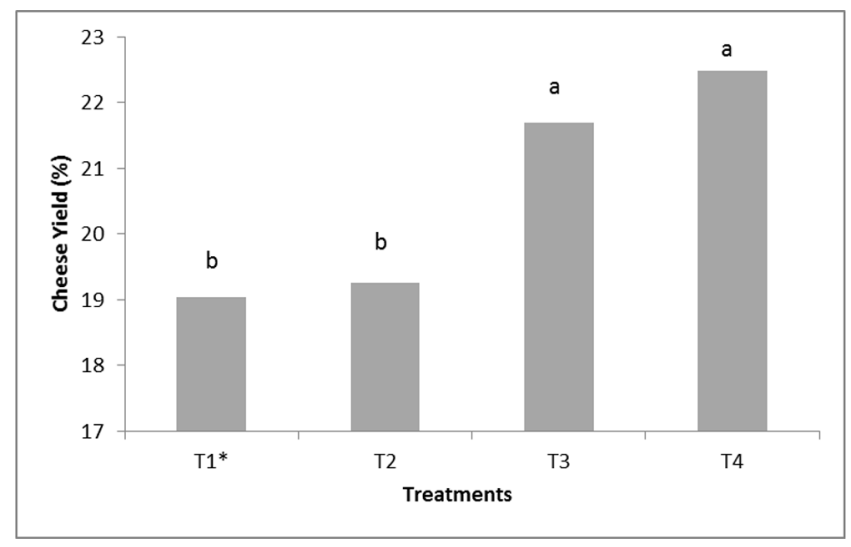

Figure 2. Percent yield $(\mathrm{w} / \mathrm{w})$ of Costeño cheese elaborated ${ }^{* *}$.

${ }^{*}$ Control Treatment, ${ }^{* *}$ Mean with different letters in graphic indicate statistically significant difference $(P<0.05)$ 


\subsection{Sensory Analysis of Cheese}

It was evidenced that pasteurization significantly affected the sensory properties of Costeño cheese $\left(\mathrm{T}_{2}\right)$ compared to the control cheese $\left(\mathrm{T}_{1}\right)$.

Panelists expressed a higher preference for traditional cheese compared to $\mathrm{T}_{2}$ treatment, in which prior milk pasteurization was used. Related results were reported for Cheddar cheese where panelists gave the highest score to cheese elaborated with fresh milk (raw), exalting a more intense flavor, characteristic of this type of product. In ${ }^{26,27}$ reported related results on taste preference of cheeses from fresh milk (raw).

Results of the sensory analysis show that the highest preference was given to cheeses made with addition of lactic cultures $\left(\mathrm{T}_{3}\right.$ and $\left.\mathrm{T}_{4}\right)$. Although $\mathrm{T}_{3}$ treatment was the highest, it did not present a significant difference in the sensory evaluation with $\mathrm{T}_{4}$ treatment (Figure 3). In reported related results ${ }^{13}$ where the panelists' preference is higher in treatments using lactic cultures on cheese samples elaborated with fresh milk (raw) and without lactic cultures addition. These researchers reported better sen-

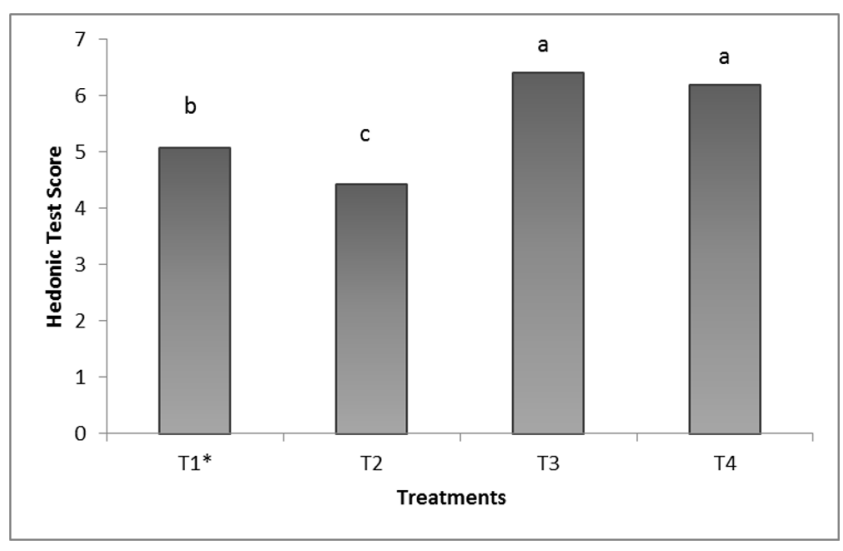

Figure 3. Hedonic Test Score ${ }^{\star *}$.

${ }^{\star}$ Control Treatment, ${ }^{* \star}$ Mean with different letters in graphic indicate statistically significant difference $(P<0.05)$ sory results in cheese elaborated with pasteurized milk and the addition of L. lactis and L. cremoris (1:1).

\subsection{Microbiological Analysis of Cheese}

There wasn't significant difference among treatments at the microbiological level (Table 4), except for yeast and mold counts in the control treatment $\left(\mathrm{T}_{1}\right)$, which was significantly higher.

The given results are within the standards reported by the Colombian Technical Standard 750 (NTC 750) and correspond to the established for a cheese of excellent microbiological quality. $\mathrm{In}^{18}$ reported related results in Costeño cheese making with lactic starter culture addition

\section{Conclusion}

The commercial lactic cultures used in this study were: $\mathrm{MT}_{12}$ (Lactobacillus bulgaricus, L. helveticus and Streptococcus thermophilus) and the mixture of $\mathrm{MT}_{12}$ with L. lactis and L. cremoris, constitute a good option for the elaboration of costeño cheese, due to the increase that these cause in product yield regarding cheese typically made with fresh milk (raw) without lactic starter culture addition. Also, the addition of this type of cultures improves sensory quality of cheese even when it is made with pasteurized milk.

This study showed that the combination of lactic cultures used allows production of high-quality Costeño cheese with excellent physical-chemical properties like those from traditional cheese elaborated fresh milk (raw) and of greater acceptance by consumers.

\section{Acknowledgement}

A special thanks to the University of Sucre for the support to the realization of this study.

Table 4. Microbial analysis of cheese ${ }^{* *}$

\begin{tabular}{|c|c|c|c|c|c|}
\hline \multirow[t]{2}{*}{ Treatment } & Total Coliforms & Fecal Coliforms & Staphylococcus aureus & Yeast and Molds & Salmonella \\
\hline & $\operatorname{Bac}(100 g)^{-1}$ & $\operatorname{Bac}(100 \mathrm{~g})^{-1}$ & $(\mathrm{UFC}) \mathrm{g}^{-1}$ & $(\mathrm{UFC}) \mathrm{g}^{-1}$ & $\operatorname{Bac}(25 \mathrm{~g})^{-1}$ \\
\hline $\mathrm{T} 1^{\star}$ & $<100^{\mathrm{a}}$ & $<3^{\mathrm{a}}$ & $<100^{\mathrm{a}}$ & $<5000^{\mathrm{a}}$ & Negative $^{\mathrm{a}}$ \\
\hline $\mathrm{T} 2$ & $<100^{\mathrm{a}}$ & $<3^{\mathrm{a}}$ & $<100^{\mathrm{a}}$ & $<500^{\mathrm{b}}$ & Negative $^{\mathrm{a}}$ \\
\hline T3 & $<100^{\mathrm{a}}$ & $<3^{\mathrm{a}}$ & $<100^{\mathrm{a}}$ & $<500^{\mathrm{b}}$ & Negative $^{\mathrm{a}}$ \\
\hline $\mathrm{T} 4$ & $<100^{\mathrm{a}}$ & $<3^{\mathrm{a}}$ & $<100^{\mathrm{a}}$ & $<500^{\mathrm{b}}$ & Negative $^{\mathrm{a}}$ \\
\hline
\end{tabular}

${ }^{\star}$ Control Treatment, ${ }^{* *}$ Mean with different letters in columns indicate statistically significant difference, Tukey $(\mathrm{p}<0.05)$ 


\section{References}

1. FEDEGAN. Federación Colombiana de Ganadero Formulario de Precios [Internet]. [cited 2018 Nov 02]. Available from: http://www.fedegan.org.co.

2. FAO. Food and Agriculture Organization of the United Nations [Internet]. [cited 2018 Oct 18]. Available from: https://en.wikipedia.org/wiki/Food_and_Agriculture_ Organization.

3. DANE. Departamento de Sucre [Internet]. [cited 2014 Nov]. Available from: https://www.dane.gov.co/files/ icer/2014/ICER_Sucre2014.pdf.

4. Calderon A, Arteaga M, Rodriguez V, Arrieta G, Bermudez D, y Villareal V. Efecto de la mastitis subclínica sobre el rendimiento en la fabricación del queso coste-o. Biosalud. 2011; 10(2):16-27.

5. Lopez J, Rodriguez E y Sepulveda J. Evaluación de Características Físicas y Texturales de Pandebono. Acta Agronómica. 2012; 61(3):273-81.

6. Kousta M, Mataragas M, Skandamis P, Drosinos E. Prevalence and sources of cheese contamination with pathogens at farm and processing levels. Food Control. 2010; 21(6):805-15. https://doi.org/10.1016/j.foodcont. 2009.11.015

7. Ryser E. Safety of dairy products. Microbial Food Safety. New York: Springer; 2011. p. 127-45.

8. Bruno V, Glikmann R, Intorno G. Foro Internacional Electrónico. Producción, Aplicación y Acción de los Cultivos lácticos. Primera parte; 2011.

9. Mangia N, Murgia M, Fancello F, Nudda A, Deiana P. Influence of Myrtle juice and syrup on microbiological, physicochemical and sensory features of goat's milk yogurt made with indigenous starter culture. Journal of Microbial and Biochemical Technology. 2014; 6:370-4. https://doi.org/10.4172/1948-5948.1000171

10. Settanni L, Moschetti G. New trends in technology and identity of traditional dairy and fermented meat production processes. Trends in Food Science and Technology. 2014; 37(1):51-8. https://doi.org/10.1016/j. tifs.2014.02.006

11. AOAC International. Official Methods of Analysis of AOAC International. 19th Edition. Latimer GW, editor. Gaithersburg. MD, USA. Official Method; 2012.

12. Jimenez D, Chima N. Caracterización de la Producción Artesanal de Queso en el Area Rural de la Subregión Golfo de Morrosquillo, Sucre-Colombia. Tesis. Universidad de Sucre, Sincelejo, Colombia; 2006.

13. Serpa J, Pérez T, Hernández E. Effect of Pasteurization and Starter Cultures on Physicochemical and Microbiological
Properties of Coste-o Cheese. Revista Facultad Nacional de Agronomía. 2016; 69(2):8007-14.

14. Powell I, Broome M, Limsowtin J. Cheese starter cultures: General aspects. Encyclopedia of Dairy Sciences. 2011; 2:552-8.

15. Londo-o A, Durango M, Sepúlveda J, Moreno C. Characterization of lactic acid bacterial communities associated with a traditional colombian cheese: Double cream cheese. LWT - Food Science and Technology. 2017; 82: 39-48. https://doi.org/10.1016/j.lwt.2017.03.058

16. Ruggirello M, Cocolin L, Dolci P. Fate of Lactococcus lactis Starter Cultures During Late Ripening in Cheese Models. Food Microbiology. 2016; 59:112-18. https://doi. org/10.1016/j.fm.2016.05.001. PMid:27375251

17. Morales M, Lobato C, Alvarez J, Vernon E. Effect of milk pasteurization and acidification method on the chemical composition and microstructure of a Mexican pasta filata cheese. Food Science and Technology. 2012; 45(2): 132-41.

18. Ballesta I. Evaluación de la Calidad del Queso Coste-o Elaborado con Diferentes Tipos de Cuajo (Animal y Microbiano) y la Adición o no de Cultivos Lácticos (Lactococcus lactis Subps. Lactis Y Lactococcus lactis Subps. Cremoris). Tesis, Universidad Nacional de Colombia, Medellin, Colombia; 2014. p. 1-105.

19. Tabet E, Mangia N, Mouannes E, Hassoun G, Helal Z, Deiana P. Characterization of Goat Milk from Lebanese Baladi Breed and its Suitability for Setting up a Ripened Cheese using a Selected Starter Culture. Small Ruminant Research. 2016; 140:13-17. https://doi.org/10.1016/j.smallrumres.2016.05.011

20. Ramírez C, Vélez J. Quesos Frescos, Métodos de Determinación y Factores que Afectan su Calidad. Temas selectos de Ingeniería de Alimentos. 2012; 6(2):131-48.

21. Zisu B, Shah N. Textural and functional changes in lowfat mozzarella cheeses in relation to proteolysis and microstructure as influenced by the use of fat replacers, pre-acidification and EPS starter. International Dairy Journal. 2005; 15(6-9):957-72. https://doi.org/10.1016/j. idairyj.2004.09.014

22. Faria V, Hennet J. Producción de un queso a partir de leche pasteurizada utilizando cultivos inocuos. Universidad del Zulia. Maracaibo, Venezuela; 2008.

23. Recinos H. Efecto de la Temperatura de Cocción de la Cuajada y Presión del Prensado en las Características Fisicoquímicas y Sensoriales del Queso Seco. Tesis, Escuela Agricola Panamericana Zamorano. Zamorano, Honduras; 2007. p. 1-26.

24. Guarcello R, Carpino S, Gaglio R, Pino A, Rapisarda T, Caggia C, Marino G, Randazzo C, Settanni L, Todaro M. 
A large factory-scale application of selected autochthonous lactic acid bacteria for PDO Pecorino Siciliano cheese production. Food Microbiology. 2016; 59:66-75. https://doi. org/10.1016/j.fm.2016.05.011. PMid:27375245

25. García B. Caracterización fisicoquímica de diversos tipos de quesos elaborados en el Valle de Tulancingo con el fin de proponer normas de calidad. Tesis, Universidad Autónoma del Estado de Hidalgo. Hidalgo, México; 2006.
26. Galicia J. Atributos sensoriales de algunos quesos menonitas producidos en la zona noroeste del estado de Chihuahua. Tesis, Universidad Autónoma de Chihuahua. Chihuahua, México; 2005.

27. Sameh A. Texture and Flavor Development in Ras Cheese Made from Raw and Pasteurized Milk. Food Chemistry. 2006; 97(3):394-400. https://doi.org/10.1016/j.foodchem. 2005.05.012 